\title{
Penguatan Karakter Peduli Lingkungan di Pesantren Modern Al Barokah Melalui Pengelolaan Sampah dan Pemanfaatan Biopori
}

\author{
Muhammad Komarul Huda (1)*, Salome Rajagukguk (2) \\ Program Studi Pendidikan Biologi Universitas Simalungun \\ *Co author: Muhammad Komarul Huda \\ mkomarulhuda@gmail.com, rajagukguksalome1967@gmail.com
}

\begin{abstract}
ABSTRAK
Sampah yang dihasilkan manusia 60-70\% merupakan sampah organik dan selebihnya sampah anorganik. Sementara pengelolaan sampah masih belum berjalan dengan baik, sehingga menyebabkan pencemaran lingkungan. Untuk itu perlu ditanamkan kepedulian lingkungan sejak dini agar menjadi kebiasan-kebiasan baik dan guru juga menjadi contoh bagi siswa-siswanya. Maka perlu dilakukan penelitian penguatan karakter peduli lingkungan melalui pengelolaan sampah dan pemanfaatan biopori guna membangun budaya peduli lingkungan di Pesantren modern al barokah. Hasil penelitian ini menunjukkan terdapat peningkatan kepedulian lingkungan dari siswa kategori rendah $(32,92 \%)$ hingga tinggi $(80,42 \%)$, berdasarkan tiga treatment dalam penguatan karakter peduli lingkungan antara lain: edukasi pemilahan sampah dan biopori, pembuatan lubang resapan biopori, pengelolaan sampah organik dan anorganik.
\end{abstract}

Kata Kunci : Karakter Peduli Lingkungan, Pengelolaan Sampah, Biopori

\begin{abstract}
$60-70 \%$ of the waste produced by humans is organic waste and the rest is inorganic waste. Meanwhile, waste management is still not running well, causing environmental pollution. For this reason, it is necessary to instill environmental awareness from an early age so that it becomes good habits and teachers are also examples for their students. So it is necessary to do research to strengthen the character of caring for the environment through waste management and the use of biopores to build a culture of caring for the environment in Al Barokah Modern Islamic Boarding School. The results of this study indicated that there was an increase in environmental awareness from low $(32.92 \%)$ to high $(80.42 \%)$ categories of students, based on three treatments in strengthening the character of environmental care, including: education on sorting waste and biopores, making biopore infiltration holes, managing organic and inorganic waste.
\end{abstract}

Keywords : Environmentallu Friendly Character, Waste Management, Biopore 
Komarul Huda M, Rajagukguk S : Penguatan Karakter Peduli Lingkungan Di Pesantren Modern Al Barokah Melalui Pengelolaan Sampah dan Pemanfaatan Biopori

\section{PENDAHULUAN}

\section{Latar Belakang}

Indonesia memiliki populasi pesisir sebesar 187,2 juta yang setiap tahunnya menghasilkan 3,22 juta ton sampah plastik yang tak terkelola dengan baik. Berdasarkan penelitian yang dilakukan oleh Jenna R. Jambeck dari University of Georgia, Indonesia merupakan negara dengan jumlah pencemaran sampah plastik ke laut terbesar kedua di dunia (Taufan Adharsyah, 2019). Tidak dapat dipungkiri, sampah akan selalu ada selama aktivitas kehidupan masih terus berjalan. Setiap tahunnya, dapat dipastikan volume sampah akan selalu bertambah seiring dengan pola konsumerisme masyarakat yang semakin meningkat (Suryani, 2014). Komposisi sampah yang dihasilkan dari aktivitas manusia adalah sampah organik sebanyak $60-70 \%$ dan sisanya adalah sampah non organik 30-40\%, sementara itu dari sampah non organik tersebut komposisi sampah terbanyak kedua yaitu sebesar $14 \%$ adalah sampah plastik. Sampah plastik yang terbanyak adalah jenis kantong plastik atau kantong kresek selain plastik kemasan (Purwaningrum, 2016). Pengelolaan sampah yang belum berjalan baik dan terus meningkatnya sampah yang dihasilkan oleh aktivitas manusia perlu dilakukan berbagai upaya untuk menunjang lingkungan hidup lebih baik. Upaya yang dapat di lakukan antara lain melalui bank sampah (Suryani, 2014), sedekah sampah (Hasanah, Husamah, Harventy, \& Satiti, 2018), Aksi 9 R (Siti Kusuma Wuryanti, n.d.), mengurangi sampah plastik (Purwaningrum, 2016), gerakan jumput sampah (Hartatik, 2016) dan penanaman etika lingkungan (Mulyana, 2009). Upaya-upaya pengelolaan sampah pastinya masih sangat banyak lagi yang dapat dilakukan, baik pada komunitas masyarakat ataupun jalur pendidikan formal. Kebiasaan yang di bangun untuk peduli lingkungan, sudah semestinya di lakukan sejak dini dan seorang guru memberikan contoh teladan dalam melakukannya (Hartatik, 2016) dan yang paling penting pendidikan lingkungan hidup harus berdasarkan pengalaman langsung bersentuhan dengan lingkungan hidup sehingga diharapkan pengalaman langsung tersebut dapat membentuk perilaku, nilai dan kebiasaan untuk menghargai lingkungan (Surakusumah, 2009). Implementasi kebiasaan dalam peduli lingkungan dapat menjadikan karakter yang melekat pada peserta didik berdasarkan pengalaman belajar, mengamati dan bersentuhan langsung saat di lingkungan sekolah maupun pada lingkungan sekitarnya. Penerapan dalam tumbuh kembang karakter salah satunya berada pada lingkungan kepesantrenan yang memuat nilai-nilai pendidikan karakter tentang makna karakter yang baik dan cara menanamkan nilai. Dalam pendidikan di pesantren disebut ta"lîm (pengajaran) dan ta"dîb (pembiasaan dengan kesadaran) (Whasfi Velasufah, 2019). Pesantren modern memiliki program pendidikan yang disusun sendiri (mandiri) dimana program ini mengandung proses pendidikan formal, non formal maupun informal yang berlangsung sepanjang hari dalam satu pengkondisian di asrama (Tolib, 2015). Dengan adanya program mandiri secara formal, non formal dan informal di lingkungan pesantren hal ini menjadi leluasa untuk menumbuh kembangkan nilai-nilai karakter peduli lingkungan, mengingat peserta didik berada 24 jam (asrama) di pesantren.

\section{Perumusan Masalah}

Banyak upaya untuk menunjang lingkungan lebih baik namun dalam penelitian ini hanya berfokus pada penguatan karakter peduli lingkungan peserta didik melalui pengelolaan sampah dan pemanfaatan biopori. Penguatan karakter peduli lingkungan dapat di terapkan pada lingkungan formal, informal dan non formal. Penelitian ini hanya di batasi pada pendidikan formal yang terjadi di lingkungan pesantren mengingat nilai-nilai yang tertuang pada pendidikan pesantren dan lebih leluasa dalam menerapkannya mengingat peserta didik berada 24 jam di pesantren (asrama). 
Komarul Huda M, Rajagukguk S : Penguatan Karakter Peduli Lingkungan Di Pesantren Modern Al Barokah Melalui Pengelolaan Sampah dan Pemanfaatan Biopori

\section{Tujuan Penelitian}

Penelitian ini bertujuan untuk memberikan penguatan karakter peduli lingkungan pada peserta didik melalui pengelolaan sampah dan pemanfaatan biopori

\section{Manfaat Penelitian}

Penelitian ini bermanfaat bagi siswa untuk meningkatkan kepedulian lingkungan dengan pengelolaan sampah dan pemanfaatan biopori. Selain bermanfaat untuk siswa, penelitian ini bermanfaat untuk sekolah demi meningkatkan kesadaran peduli lingkungan bahkan dapat dijadikan langkah awal menuju sekolah adiwiyata.

\section{METODE PENELITIAN}

Jenis penelitian yang digunakan dalam penelitian ini adalah deskriptif kuantitatif. Dimana data yang di peroleh akan di analisis secara statistik dan dideskripsikan berdasarkan data yang ada. Adapun data yang di kumpulkan berupa hasil observasi peduli lingkungan pada beberapa tahapan treatmant penelitian. Pengamatan peduli lingkungan oleh santri pesantren modern Al barokah selama tiga pekan dengan Treatmant penelitian seperti pada gambar 2.1.

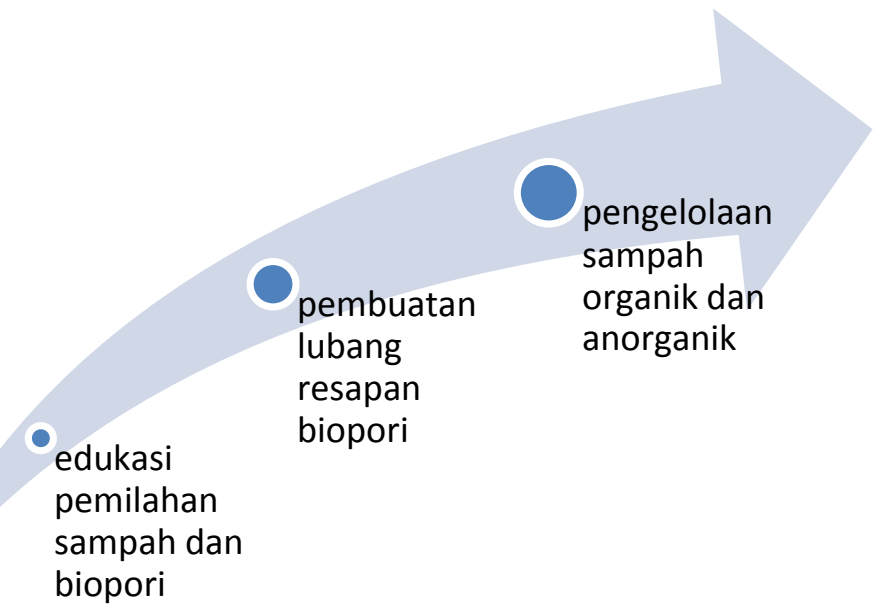

Gambar 1 Treatment penelitian dalam memperkuat karakter peduli lingkungan

\section{Populasi dan sampel}

Populasi penelitian adalah siswa kelas X MA (Madrasah Aliyah) Pesantren Modern Al barokah yang terdiri dari 3 kelas dengan jumlah siswa sebanyak 63 orang. Kelas X di pilih sebagai populasi penelitian disebabkan terdapat materi pencemaran lingkungan pada mata pelajaran biologi, bertujuan mempermudah dalam hal pemahaman lingkungan. Sampel yang di gunakan dalam penelitian ini terdiri dari 15 siswa, dengan menggunakan teknik sampling berupa proportional stratified random sampling. Langkah utama yang harus dilakukan dalam teknik sampling ini adalah menentukan terlebih dahulu jumlah sampel yang dibutuhkan, lebih lanjut menentukan berapa banyak anggota sampel setiap kelas dengan menggunakan rumus Soepono (2002:90).

$\mathrm{Spl}=\frac{n}{N} X j s$

Keterangan:

Spl : jumlah sampel pada setiap kelas

$\mathrm{N}$ : jumlah responden dalam populasi

$\mathrm{n}$ : jumlah responden dalam kelas

js : jumlah sampel yang dibutuhkan 
Komarul Huda M, Rajagukguk S : Penguatan Karakter Peduli Lingkungan Di Pesantren Modern Al Barokah Melalui Pengelolaan Sampah dan Pemanfaatan Biopori

Teknik sampling ini dipilih disebabkan Pesantren modern albarokah menerapkan grade pada tiap kelasnya, sehingga dengan dibentuknya kelas baru melalui random dapat menghindari kesenjangan pada setiap individu.

\section{Instrumen penelitian dan teknik analisa data}

Penyusunan instrumen penelitian berupa observasi peduli lingkungan, berdasarkan indikator peduli lingkungan hidup yang dikeluarkan oleh BPS (2014) dan literatur pendukung maka, disusunlah kisi-kisi observasi penguatan karakter peduli lingkungan dengan 3 variabel antara lain: pengelolaan sampah, upaya penanggulangan pencemaran lingkungan dan pelestarian flora dan fauna. Analisis data observasi menggunakan deskriptif presentase di olah dengan cara frekuensi di bagi jumlah responden di kali 100\% seperti di sampaikan sudjana (2001):

Keterangan :

$$
P=\frac{F}{N} \times 100 \%
$$

$\mathrm{P}=$ Persentase jawaban

$\mathrm{F}=$ Frekuensi jawaban responden

$\mathrm{N}=$ total frekuensi

Setelah didapatkan persentase jawaban responden selanjutnya diberikan penafsiran atau penilaian terhadap hasil penelitian. Peneliti menggunakan metode penafsiran menurut Arikunto (1998:57) seperti tabel 2.1 berikut :

Tabel 1 Kategori Nilai Persentase

\begin{tabular}{|l|l|l|}
\hline No. & $\begin{array}{l}\text { Persentase Batas } \\
\text { Interval }\end{array}$ & \multicolumn{1}{c|}{$\begin{array}{c}\text { Kategori } \\
\text { Penilaian }\end{array}$} \\
\hline 1. & $0-20 \%$ & Sangat rendah \\
\hline 2. & $21-40 \%$ & Rendah \\
\hline 3. & $41-60 \%$ & Sedang \\
\hline 4. & $61-80 \%$ & Tinggi \\
\hline 5. & $81-100 \%$ & Sangat tinggi \\
\hline
\end{tabular}

\section{HASIL}

Hasil penguatan karakter peduli lingkungan terbagi ke dalam 3 variabel pengamatan berupa indikator pengelolaan sampah rata-rata sebesar $63,89 \%$, indikator upaya penanggulangan dan pencemaran lingkungan rata-rata sebesar $47,00 \%$ dan indikator pelestarian flora dan fauna sebesar 57,67\%. Lebih detail hasil penguatan karakter peduli lingkungan berdasarkan 3 variabel dapat di lihat pada tabel 3.1.

Tabel 2. Hasil penguatan karakter peduli lingkungan berdasarkan 3 variabel

\begin{tabular}{|l|c|c|c|c|}
\hline \multicolumn{1}{|c|}{ Variabel } & $\begin{array}{c}\text { Observasi } \\
\text { ke-1 }\end{array}$ & $\begin{array}{c}\text { Observasi } \\
\text { ke-2 }\end{array}$ & $\begin{array}{c}\text { Observasi } \\
\text { ke-3 }\end{array}$ & $\begin{array}{c}\text { Rata- } \\
\text { rata }\end{array}$ \\
\hline Pengelolaan sampah & $43,33 \%$ & $61,67 \%$ & $86,67 \%$ & $63,89 \%$ \\
\hline $\begin{array}{l}\text { Penanggulangan dan } \\
\text { pencemaran } \\
\text { lingkungan }\end{array}$ & $24,00 \%$ & $43,00 \%$ & $74,00 \%$ & $47,00 \%$ \\
\hline $\begin{array}{l}\text { Pelestarian flora dan } \\
\text { fauna }\end{array}$ & $37,00 \%$ & $52,00 \%$ & $84,00 \%$ & $57,67 \%$ \\
\hline
\end{tabular}

Secara keseluruhan penguatan observasi mengalami peningkatan pada setiap pekannya. Pada observasi ke 1 pengamatan dilakukan selama satu pekan oleh observer, menunjukkan hasil sebesar 32,92\%. Rendahnya peduli lingkungan pada observasi ke 1 disebabkan masih 
Komarul Huda M, Rajagukguk S : Penguatan Karakter Peduli Lingkungan Di Pesantren Modern Al Barokah Melalui Pengelolaan Sampah dan Pemanfaatan Biopori

dalam tahap adaptasi para siswa dalam menanamkan sikap peduli lingkungan. Pada observerasi pekan ke 2 mengalami peningkatan mencapai 50,42\%. Pada pekan ke 3 karakter peduli lingkungan para siswa mulai lebih baik dengan persentase sebesar $80,42 \%$. Pengamatan karakter peduli lingkungan oleh observer dilakukan setiap hari dan di evaluasi setiap pekan sekali selama 3 kali. Sehingga di hasilkan grafik penguatan karakter peduli lingkungan yang dapat di lihat pada gambar 2

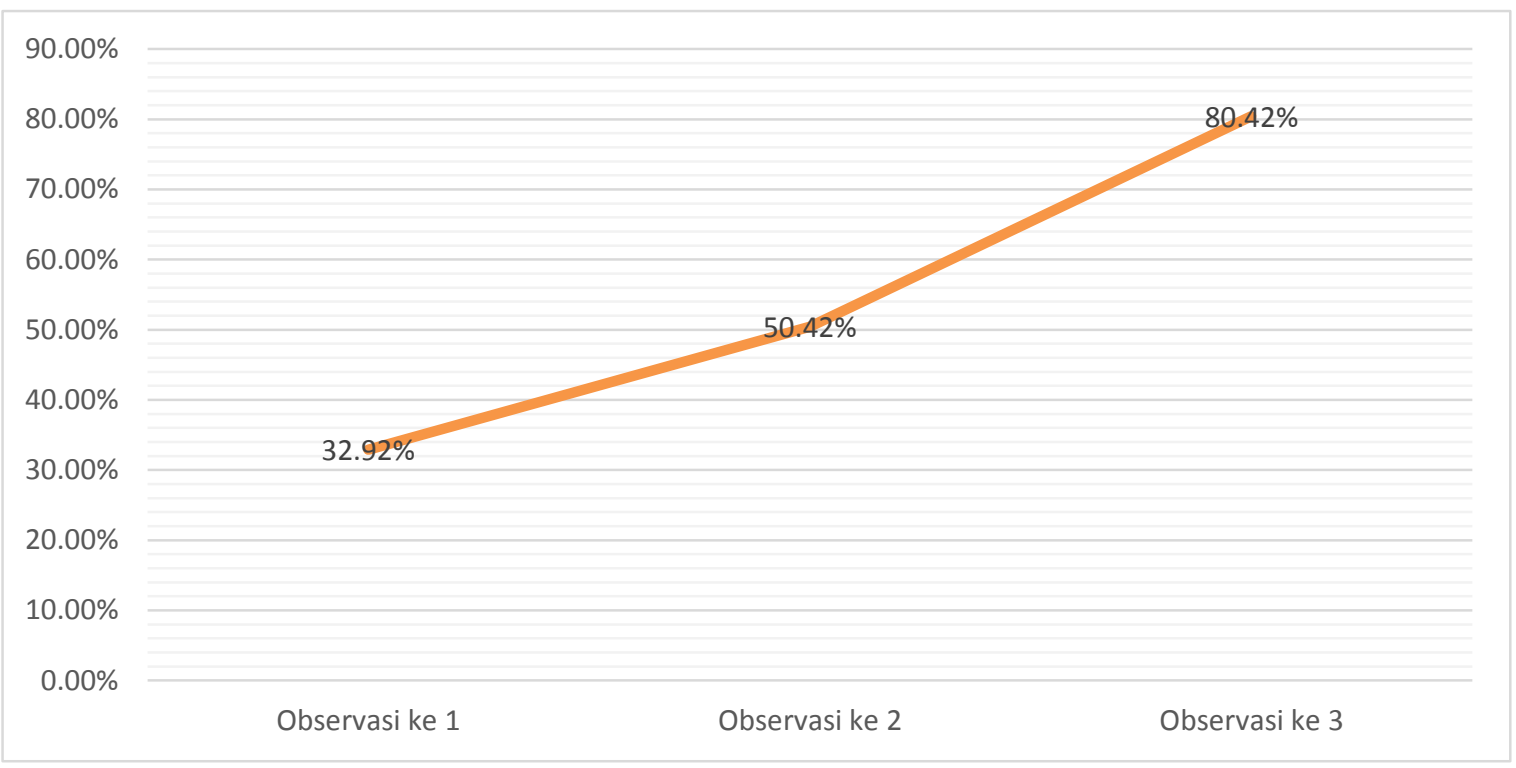

Gambar 2. Grafik Penguatan Karakter Peduli Lingkungan

Berdasarkan penafsiran atau penilaian Arikunto (1998) penguatan karakter peduli lingkungan pada pekan pertama tergolong rendah, pada pekan kedua tergolong sedang dan pada pekan ketiga mengalami peningkatan pada kategori tinggi. Penguatan karakter diberikan dikarenakan para siswa sebelumnya telah mendapatkan pembentukan karakter sejak sekolah dasar hingga sekolah menengah. untuk menanamkan karakter diperlukan konsistensi dalam pelaksanaan, artinya perlu adanya pembiasaan yang kontinyu, terusmenerus (Nurul Inayah \& Ribut Suprapto, 2017). Karakter merupakan gabungan dari kebiasaan-kebiasaan. Sementara kebiasaan-kebiasaan itu merupakan rangkaian dari perbuatan atau pengamalalanpengamalan (acting/doing) (Abas Asyafah, 2010). Sehingga kebiasan-kebiasan dalam pengelolaan sampah, upaya mencegah pencemaran dan pelestariaan flora fauna dapat membentuk dan memperkuat karakter peduli lingkungan. Pendidikan karakter pada intinya adalah mengukir akhlak melalui proses knowing the good, loving the good, dan acting the good, yaitu proses pendidikan yang melibatkan aspek kognitif, emosi, dan fisik, sehingga akhlak mulia bisa terukir menjadi habit of the mind, heart, dan hands (Mangun Budiyanto dan Imam Machali, 2014)

\section{PEMBAHASAN}

Salah satu langkah dalam memperkuat karakter peduli lingkungan adalah mengelolah sampah dan pemanfaatan biopori. Seperti hasil penelitian (Asih, 2018) dalam rangka pembentukan karakter peduli lingkungan dilaksanakan beberapa tahapan antara lain: Moral knowing (pengetahuan tentang moral dilakukan dalam bentuk pembelajaran PLH dan insert mata pelajaran), moral Feeling (perasaan tentang moral dengan menumbuhkan perasaan cinta terhadap lingkungan melalui keteladanan), moral doing (perbuatan bermoral dengan langsung praktik pengelolan sampah sekolah). Selain mengelolah sampah, penguatan 
karakter peduli lingkungan dilakukan pemanfaatan biopori dikarenakan lubang resapan biopori sangat efektif menyerap air dan dapat mengurangi sampah organik yang terbuang ke tempat pembuangan akhir (Yohana, Griandini, \& Muzambeq, 2017). Untuk mengefektifkan lubang resapan biopori terhadap laju infiltrasi (Juliandari, 2013) melakukan pengeboran tanah menggunakan hand bor dengan kedalaman $50 \mathrm{~cm}$, diameter lubang sebesar $7 \mathrm{~cm}$. Maka pada penelitian ini menggunakan kedalaman $80 \mathrm{~cm}$ dan diamater lubang sebesar 15 $\mathrm{cm}$ yang di tempatkan pada sekitaran pohon lebih kurang berjarak $1 \mathrm{~m}$ dari batang utama dengan tujuan mempercepat infiltrasi, dapat menampung sampah organik lebih banyak, dan dapat menyuburkan tanah di lokasi tumbuhan tersebut di tanam. Pembentukan karakter peduli lingkungan tidak hanya melalui pengelolaan sampah dan pemanfaatan biopori, namun banyak aktivitas atau program yang bertujuan membentuk/menguatkan karakter peduli lingkungan seperti hasil penelitian (Trahati, 2015) menunjukkan bahwa pendidikan karakter peduli lingkungan dapat dilaksanakan melalui (1) Pengembangan kurikulum sekolah meliputi program pengembangan diri, pengintegrasian dalam mata pelajaran, dan budaya sekolah. (2) Pengembangan proses pembelajaran kelas, sekolah, dan luar sekolah. (3) Pengembangan kesehatan sekolah meliputi pemeliharaan ruang dan bangunan, pencahayaan dan ventilasi udara ruang kelas yang memadai, pengelolaan fasilitas sanitasi, kantin/warung, pencegahan lingkungan dari jentik nyamuk, larangan dan penyuluhan bahaya rokok, dan promosi hygieni dan sanitasi

\section{KESIMPULAN}

Kesimpulan pada penelitian ini antara lain:

1. Pengelolaan sampah dan pemanfaatan biopori dapat dijadikan acuan dalam penguatan karakter peduli lingkungan

2. Karakter peduli lingkungan dapat terbentuk dengan baik jika dilakukan pembiasaanpembiasaan dan continiu berupa pengelolaan sampah, penanggulangan dan pencemaran lingkungan, serta pelestarian flora dan fauna

3. Pengelolaan sampah dan pemanfatan biopori merupakan salah satu langkah dalam menjaga ekosistem

\section{DAFTAR PUSTAKA}

Abas Asyafah. (2010). Mendidik karakter dengan pengamalan dan pembiasaan. 352-364.

Asih, N. T. (2018). PENGELOLAAN SAMPAH DI SEKOLAH ( Studi Tentang Pembentukan Karakter Peduli Lingkungan di SD Negeri 3 Bancarkembar Kabupaten Banyumas ). 8.

Hartatik, H. (2016). Pengaruh Gerakan Jumput Sampah Terhadap Pendidikan Karakter Siswa Dan Pemeliharaan Kebersihan Lingkungan Sekolah Di Sd Nu Kepanjen Kabupaten Malang. Jurnal Inspirasi Pendidikan, 6(1), 827. https://doi.org/10.21067/jip.v6i1.1088.

Hasanah, I., Husamah, H., Harventy, G., \& Satiti, N. R. (2018). Implementasi Sekolah Sedekah Sampah Untuk Mewujudkan Pengelolaan Sampah Berbasis Filantropi di SMP Muhammadiyah Kota Batu. International Journal of Community Service Learning, 2(4), 283-290. https://doi.org/10.23887/ijcsl.v2i4.14364.

Juliandari, M. (2013). Efektivitas Lubang Resapan Biopori Terhadap Laju Resapan (Infiltrasi). Jurnal Teknologi Lingkungan Lahan Basah, 1(1), 1-10. https://doi.org/10.26418/jtllb.v1i1.3441.

Mangun Budiyanto dan Imam Machali. (2014). Pembentukan Karakter Mandiri Melalui Pendidikan Agriculture Di Pondok Pesantren Islamic Studies Center Aswaja Lintang Songo Piyungan Bantul YOGYAKARTA. Jurnal Pendidikan Karakter, 4(2), 109-122. https://doi.org/10.21831/jpk.v0i2.2784. 
Komarul Huda M, Rajagukguk S : Penguatan Karakter Peduli Lingkungan Di Pesantren Modern Al Barokah Melalui Pengelolaan Sampah dan Pemanfaatan Biopori

Mulyana, R. (2009). Penanaman Etika Lingkungan Melalui Sekolah Perduli Dan Berbudaya Lingkungan. Jurnal Tabularasa PPS Unimed, 6(2), 175-180.

Nurul Inayah, \& Ribut Suprapto. (2017). Pendidikan Karakter melalui Pembentukan Bank Sampah Berbasis Pesantren di PP Ibnu Sina Genteng Banyuwangi. Engagement: Jurnal Pengabdian Kepada Masyarakat, 1(1), 14-27. https://doi.org/10.29062/engagement.v1i1.4.

Purwaningrum, P. (2016). Upaya Mengurangi Timbulan Sampah Plastik Di Lingkungan. Indonesian Journal of Urban and Environmental Technology, 8(2), 141. https://doi.org/10.25105/urbanenvirotech.v8i2.1421.

Siti Kusuma Wuryanti. (n.d.). Aksi 9R dalam Pengelolaan Sampah demi Lingkungan yang Lebih Baik. Retrieved from foresteract website: https://foresteract.com/aksi-9r-dalampengelolaan-sampah-demi-lingkungan-yang-lebih-baik/

Surakusumah, W. (2009). Konsep pendidikan lingkungan di sekolah: model uji coba sekolah berwawasan lingkungan. Bandung: Universitas Pendidikan Indonesia. Retrieved from http://file.upi.edu/Direktori/FPMIPA/JUR._PEND._BIOLOGI/197212031999031-

WAHYU_SURAKUSUMAH/Konsep_Pendidikan_Lingkungan_Hidup.pdf

Suryani, A. S. (2014). Peran Bank Sampah Dalam Efektivitas Pengelolaan Sampah (Studi Kasus Bank Sampah Malang). Aspirasi, 5(1), 71-84. https://doi.org/10.22212/aspirasi.v5i1.447

Taufan Adharsyah. (2019). Sebegini Parah Ternyata Masalah Sampah Plastik di Indonesia. CNBC Indonesia. Retrieved from https://www.cnbcindonesia.com/lifestyle/20190721140139-33-86420/sebeginiparah-ternyata-masalah-sampah-plastik-di-indonesia

Tolib, A. (2015). Pendidikan Di Pondok Pesantren Modern Terpadu. Risalah, 1(1), 60-66.

Trahati, M. R. (2015). IMPLEMENTASI PENDIDIKAN KARAKTER PEDULI LINGKUNGAN DI SEKOLAH DASAR NEGERI TRITIH WETAN 05 JERUKLEGI CILACAP. Jurnal Pendidikan Guru Sekolah Dasar. https://doi.org/10.1145/3132847.3132886

Whasfi Velasufah, A. R. S. (2019). Nilai pesantren sebagai dasar pendidikan karakter. Pel $\lambda$ ntan, (September), 1-8.

Yohana, C., Griandini, D., \& Muzambeq, S. (2017). Penerapan Pembuatan Teknik Lubang Biopori Resapan Sebagai Upaya Pengendalian Banjir. Jurnal Pemberdayaan Masyarakat Madani (JPMM), 1(2), 296-308. https://doi.org/10.21009/jpmm.001.2.10

\begin{tabular}{|l|l|l|l|}
\hline Accepted Date & Revised Date & Decided Date & Accepted to Publish \\
\hline 19 November 2020 & 22 November 2020 & 30 November 2020 & Ya \\
\hline
\end{tabular}

